\title{
"He just told me to get on with it": Insights into Transforming Doctoral Writing Development
}

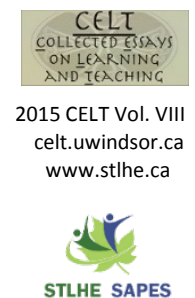

\author{
E. Marcia Johnson \\ The University of Waikato, Hamilton, New Zealand
}

This paper reports on the results of a two-year study into threshold concepts (TCS) in doctoral writing. The findings informed the development of a thinking to write strategy (the 4x4) that has been implemented as part of a pan-university doctoral writing programme at a New Zealand university.

\section{Background}

T This paper describes findings from a New Zealand two-year, qualitative research project that explored threshold concepts (TCs) in tertiary education - the point(s) at which students can become "stuck", unable to make intellectual progress. The four project case studies were all informed by threshold concept theory, which asserts that concepts that are troublesome to learn can also be transformative when mastered. Once grasped, they reconfigure students' understanding of a discipline and what it means to be a disciplinary expert. Three of the cases focused on TCs in undergraduate disciplines (English, Engineering, and Management Leadership). The fourth case (mine) was devoted to identifying TCs in doctoral writing.

Through the cross-disciplinary case studies and collaborative teamwork, the project group endeavoured to answer a key research question about how lecturers' awareness of threshold concepts could affect teacher-student discourse and pedagogical practice at the tertiary level. The team was also interested in whether there were threshold concepts that spanned disciplines. This paper focuses on two threshold concepts that were identified in the doctoral writing case study and describes how they enhanced an existing pan-university programme to support doctoral students as writers.

\section{Conceptual Framework}

\section{Threshold concepts and doctoral writing}

Meyer and Land (2003) introduced the notion of TCs that students must understand in order to think like a subject specialist and not be bothered by troublesome knowledge. According to TC theory, in each academic discipline there exist special concepts that can reveal new and previously inaccessible ways of thinking about a subject. TCs represent the intellectual places where students get stuck (Davies, 2006; Meyer \& Land, 2005; Wisker \& Savin-Baden, 2009) and are unable to make substantive progress in their academic work until the concepts are understood. 
Meyer and Land (2003, 2005) state that there are five key characteristics of TCs: crossing them is transformative, irreversible, integrative, bounded, and troublesome. They also refer to the intellectual space in which students are unable to make intellectual progress as "liminal space" and believe that it is crucial to uncover why and how some students undergo a transformational, or even a creative, experience while in the liminal space of incomplete understanding.

In the area of doctoral writing, Kiley (2009) argues that students face a number of challenges as doctoral writers and that surmounting them both requires, and facilitates, personal transformation. The development of deep understanding of such concepts as theoretical or conceptual frameworks, knowledge of how to shape complex arguments and mastery of doctoral writing conventions all require candidates to cross intellectual thresholds. Until they do, students can feel that they are making no progress in their study, which can lead to a sense of failure, isolation, or hopelessness (p. 294). Writing is the tool that helps students bridge the conceptual space of learner or novice researcher to that of "independent academic scholar", but paradoxically, being able to master doctoral writing TCs requires students to perform as though they are already academic disciplinary experts and writers.

The challenge for this case study then was to determine if there were knowable TCs in doctoral writing and if so, to develop flexible structures that could help students cross them.

\section{Two threshold concepts in doctoral writing}

Drawing on survey and interview data with doctoral students in New Zealand, Canada, and the United States, two threshold concepts (TCs) related to doctoral research writing were identified (see Johnson, 2013). The first, "talking to think", encompasses the idea that academic writing includes more than the mechanical presentation of words on a page. Until one has clarified one's thinking (and has something to say), meaningful writing is difficult and can contribute to feeling lost. The second TC, "developing self-efficacy", is closely related. Writing includes the ability to understand research practices, extract meaning from data, clearly articulate ideas (talk), and then present, shape, and reshape text on the page. Self-efficacy as an academic researcher and writer also includes a belief that understanding will emerge as new ideas are discussed, clarified, written, and refined.

Both the talking to think and self-efficacy TCs reflect Meyer and Land's five key characteristics (2003, 2005) - crossing them is transformative, irreversible, integrative, bounded, and troublesome as students become independent scholars through the process of being independent doctoral researchers and writers (scholars).

\section{Transforming doctoral support}

\section{The changing face of doctoral education and supervision}

In 2006 the New Zealand government introduced a policy of charging domestic enrolment fees to international doctoral students with the result that the cost for overseas students declined approximately five-fold. Predictably the numbers of doctoral students escalated sharply over the next several years (Gerritsen, 2010), which was not matched by an equivalent growth in staff numbers (Sampson \& Comer, 2010). Moreover, this situation is not unique to New Zealand; worldwide the number of doctoral students has increased exponentially over the past 15 years (OECD, 2013).

In spite of increased student numbers, the pool of suitably qualified supervisors within most institutions has remained relatively static. One can argue that reliance on time-intense, individuallyoriented supervisory practice has become a luxury, which is increasingly difficult for universities to sustain. Yet, as Halse and Bansel (2012, p. 378) note, "the default model of the doctorate remains an individualised relationship between student and 
academic supervisor involving the preparation and supervision of a thesis/dissertation". Colbeck (2007) remarks that even distinguished scholars often find it difficult to abandon traditional models of practice. What follows is a discussion of how one university has developed an effective writing support programme for its doctoral students.

\section{The doctoral writing conversation (DWC)}

Being involved in the research project and learning about threshold concepts was interesting, but transforming the findings into practical doctoral writing support has been another matter entirely. This has involved developing and implementing practical, straightforward, yet powerful ways of helping students achieve their writing goals while at the same time supporting (busy) supervisors. Certainly telling students to "just get on with it" is not only unhelpful, it indicates a lack of understanding that the concept of self-efficacy is complex, value-laden, and must be disaggregated in order to help students cross intellectual thresholds.

The DWC is a pan-university, crossdisciplinary forum for doctoral students that began in 2009. The university learning developers run the DWC for two hours every Friday morning from March to July and then from August to November. Finally, two, 2-day writing retreats are offered and provide quiet time for students to write, seek writing assistance from a learning developer in a break-out session, and network over morning teas and lunch.

The DWC has evolved from an initial "hit and miss" selection of topics to a predictable format. During the first week of each month, two or three invited academic staff from across university disciplines will participate in informal conversations with doctoral students around specific research or writing themes. In Weeks 2 and 3 the learning developers or other academic staff from across the university offer interactive workshops about specific themes relating to writing, digital literacy, or research methods. The focus in these sessions is on having students engage with ideas and tasks so as to better understand doctoral writing requirements. In Week 4, students bring small samples of their own writing, for which they would like feedback, and they then work with learning developers and peers to offer and receive advice on how to improve their writing. Again, these sessions are dialogic, small group in nature, and provide both social and intellectual opportunities to engage in writing. The DWC programme thus provides a total of twenty-four regular sessions and four days of intensive writing retreats across the year.

\section{The $4 \times 4$ strategy}

One of the strategies that is used in the DWC is the "4x4" (pronounced "four by four"). This strategy provides a flexible, but highly structured framework for students to identify topics, articulate ideas, converse about outcomes, and then plan what they need to do next to make progress. By so doing, students are involved in focused discussion, with an educated "other" outside of their subject discipline, so that they can clarify their thinking through conversation ("talking to think").

In the first step, working in pairs or small groups, students focus on a chapter or section of their writing and identify four ideas that they wish to communicate to a reader. This activity functions as a limiting mechanism so that the ensuing group discussion can achieve depth, rather than be just a quick skate across the surface. Students might be working on parts of their proposal, conceptual framework, organisation of a literature review or findings section, and be unsure about how to connect the ideas or articulate them clearly and logically.

Step two requires students to articulate their ideas (in layman's terms) with their partner or small group. The articulation activity is extremely powerful because it can expose students' certainties and uncertainties. As students talk, they have to make connections between their written ideas, which can lead to a realization of where more explicit links are needed in order to gain coherence (for example). 
In step three of the strategy, we ask students to converse - to engage in more general discussion with the wider group. They are encouraged to ask questions of one another, expand on their initial four points, or incorporate other ideas from other contexts. This is the stage that we find most valuable because the sharing of ideas within the wider group, with people from outside their own discipline, helps students to consider their topic or their writing in new ways.

In the final, fourth step of the strategy students then plan their next actions. This can include making decisions about which sections they should focus on first; which sections need rereading and revision; what additional sources need to be found and read; or what additional discussions (with supervisors or peers) need to be had. Although discussion is helpful and can lead students to make their implicit knowledge explicit, talking is not enough. At some point, students need to "just do it" - but now, they can do so from an enhanced sense of mental clarity, a deeper understanding of how ideas need to be structured and presented in their writing, and an improved feeling of confidence and independence.

Depending on the stage of their thesis at which students are working, they might need to think about focusing their topic; the particular processes or methods they need to use; which goals or outcomes should be a priority; or what human or physical resources are available to assist them. Thus, even within the limited time-frame of a $4 \times 4$ session, students perceive that they can make writing progress and that structured peer input is valuable.

\section{Discussion and Conclusion}

Engaging in critical conversation with small groups of their peers and then reporting back to a larger group has afforded students opportunities to clarify their ideas during $4 \times 4$ sessions. The DWC's crossdisciplinary nature requires participants to be very clear when describing the complex chemical properties of concrete to an applied linguist, for example. Students report that they have gained new insights that have extended their thinking and as a result have been able to address conceptual gaps, improve planning processes, write more effectively, and use supervisory sessions more productively.

So I think some of the advantage of Doctoral Writing is that it breaks down the barriers and you can see what other people are doing and see the inter-connections, and think, "Ooh, I could write with that person!" The interconnections that you make in things like this are actually teaching these valuable skills. [Student A focus group]

The $4 \times 4$ also goes beyond what is described in other literature about doctoral writing where the focus has been on peer editing practice (Aitchison, 2009). Instead, our learning developers step back from the written page and through conversation help students develop their ideas orally and then plan with an "educated other" how to enact organizational writing structures to bridge from the spoken to the written. It can be argued that peer editing, while extremely valuable, is only one step in the writing cycle but that formulating and articulating ideas orally with a peer mentor needs to occur first.

One of the best things is that we become more critical, not of people, but say 'how to do something'. We might say, "I can't see that you've actually got your critical framework grounded - it's sort of not making sense." So we are actually up-skilling ourselves. [Student B focus group]

In addition, beyond the $4 \times 4$ sessions, the collegiality of student discussions across all of the different DWC sessions has created a physical network of social and learning support for higher degree students at the university that extends what supervisors can provide.

I like coming to those sessions because they are talking about things that I need to know more about, but I don't want to hassle my supervisors about it. I don't want to wear 
them out. I like to ask those questions that I may have asked my supervisor, but did not get an explanation that satisfied me. [Student C focus group]

Insights gained from the DWC have assisted the learning developers to help students identify and make explicit what it means to be a doctoral writer. This includes understanding that writing is far more than the physical act of putting words on the page, but that it incorporates the ability to understand research practices, extract meaning from data, clearly articulate ideas, and then present, shape, and reshape text on the page. Understanding writing also means developing an enhanced tolerance of ambiguity while searching for meaning, and of particular note, it includes the belief that understanding will emerge as ideas are discussed, clarified, written, and refined through practice.

The $4 \times 4$ sessions within the DWC programme are popular, and we have found that the strategy is a valuable tool to help doctoral students structure their thinking and make writing breakthroughs. Sometimes we just need the right advice at the right time and even a relatively simple activity such as the $4 \times 4$ can be just what is needed.

\section{References}

Aitchison, C. (2009). Writing groups for doctoral education. Studies in Higher Education, 34, 905-916. http://dx.doi.org/10.1080/0307 5070902785580

Colbeck, C. L. (2007). Envisioning the future of doctoral education: Preparing stewards of the discipline - Carnegie essays on the doctorate (review). The Journal of Higher Education, 78, 611-613. http://dx.doi.org/10.1353/ jhe.2007.0033

Davies, P. (2006). Threshold Concepts: How can we recognise them? In R. Land \& J. H. F Meyer
(Eds.), Threshold concepts and troublesome knowledge (pp. 70-84). London, England: Routledge.

Gerritsen, J. (2010, February 21). New Zealand fee policy attracts foreign $\mathrm{PhD}$ students. University World News. Retrieved from http://www.universityworldnews.com/articl e.php?story $=20100219130536770$

Halse, C., \& Bansel, P. (2012). The learning alliance: Ethics in doctoral supervision. Oxford Review of Education, 38, 377-392. http://dx.doi.org/ 10.1080/03054985.2012.706219

Johnson, E. M. (1 - 4 July, 2013). "Previously I thought writing was writing": Reflections on doctoral writing spaces. In S. Frielick, N. Buissink-Smith, P. Wyse, J. Billot, J. Hallas, \& E. Whitehead (Eds.). Research and Development in Higher Education: The Place of Learning and Teaching, 36, (pp. 233 242). Auckland, New Zealand. Retrieved from http://www.herdsa.org.au/wp-content /uploads/conference/2013/HERDSA_2013 _JOHNSON.pdf

Kiley, M. (2009). Identifying threshold concepts and proposing strategies to support doctoral candidates. Innovations in Education and Teaching International, 46, 293-304. http://dx.doi.org/10.1080/1470329090306 9001

Meyer, J. \& Land, R. (2003). Threshold concepts and troublesome knowledge: Linkages to ways of thinking and practising within the disciplines. (Occasional Report 4). Retrieved from the Enhancing Teaching-Learning Environments in Undergraduate Courses website: http://www.etl.tla.ed.ac.uk/docs/ETLreport 4.pdf

Meyer, J., \& Land, R. (2005). Threshold concepts and troublesome knowledge (2): Epistomological considerations and a 
conceptual framework for teaching and learning. Higher Education, 49, 373-388. http://dx.doi.org/10.1007/s10734-004-677 $9-5$

OECD. (2013). Education at a Glance 2013: OECD Indicators. OECD Publishing. http://dx.doi. org/10.1787/eag-2013-en

Sampson, K., \& Comer, K. (2010). When the governmental tail wags the disciplinary dog: Some consequences of national funding policy on doctoral research in New Zealand. Higher Education Research \& Development, 29, 275-289. http://dx.doi.org/10.1080/072 94360903277372

Wisker, G., \& Savin-Baden, M. (2009). Priceless conceptual thresholds: Beyond the 'stuck place' in writing. London Review of Education, 7, 235-247. http://dx.doi.org/10. 1080/14748460903290207

\section{Acknowledgements}

The author gratefully acknowledges funding support from the Teaching and Learning Research Initiative, New Zealand Council for Educational Research, Wellington, New Zealand.

\section{Biography}

E. Marcia Johnson has a Ph.D. in Computer Applications in Education from the University of Toronto and taught in an Applied Linguistics department in New Zealand. She is currently Director, Centre for Tertiary Teaching \& Learning, University of Waikato, Hamilton, New Zealand. 